\title{
Determination of toxic effects of deltamethrin on the primary gill cell culture of Lake Van fish [Alburnus tarichi (Güldenstadt 1814)]
}

\author{
Elif KAVAL OĞUZ
}

Van Yüzüncü Yal University, Faculty of Education, Science Education, 65080, Van, Turkey ORCID ID: Elif KAVAL OĞUZ: https:/ / orcid.org/0000-0003-0196-2693

\begin{abstract}
Received: 08.10 .2021
Accepted: 22.11.2021

Published online: 05.12 .2021

Issue published: 31.12 .2021

Abstract: Lake Van fish is one of few vertebrate species living in the lake, therefore it plays a very useful role as an indicator in determining lake pollution. Deltamethrin (DLT) is one of the pesticides used extensively in the Lake Van basin. In this study, it was aimed to determine the effects of DLT on the primary gill cell culture. Different concentrations of DLT $(0.01,0.1,1$, and $10 \mu \mathrm{M}$ ) were added to primary gill cell culture and the total antioxidant and oxidant levels, malondialdehyde (MDA), and 8hydroxy-2'-deoxyguanosine (8-OHdG) levels were determined at the end of 24 and $48 \mathrm{~h}$ of administration. While the highest concentration of applied DLT $(10 \mu \mathrm{M})$ caused a significant increase in the total oxidant level at $48 \mathrm{~h}$, a decrease in the total antioxidant level was detected at 24 and $48 \mathrm{~h}(\mathrm{P}<0.05)$. The increase in MDA level, which is the product of lipid peroxidation of unsaturated fatty acids, with DLT concentrations of $1-10 \mu \mathrm{M}$ at the end of 24 and $48 \mathrm{~h}$ was found to be significant $(\mathrm{P}<0.05)$. As a result, it can be said that DLT caused oxidative stress in the primary gill cell culture of Lake Van fish exposed to concentrations of 1 and $10 \mu \mathrm{M}$, but no genotoxic effect was observed.
\end{abstract}

Keywords: Pesticide, Oxidative stress, Lipid peroxidation, DNA damage, Lake Van.

\section{Van Gölü Balıklarının [Alburnus tarichi (Güldenstadt 1814)] Birincil Solungaç Hücre Kültüründe Deltametrinin Toksik Etkilerinin Belirlenmesi}

\begin{abstract}
Öz: Van Gölü balığı, Van Gölü'nde yaşayan az sayıdaki omurgalı türlerinden biridir bu yüzden gölün kirliliğinin belirlenmesinde çok önemli bir gösterge olarak rol almaktadır. Deltamethrin (DLT), Van Gölü havzasında yaygın olarak kullanılan pestisitlerden biridir. Bu çalışmada, DLT'nin primer solungaç hücre kültürü üzerine etkilerinin belirlenmesi amaçlanmıştır. Primer solungaç hücre kültürüne farklı konsantrasyonlarda $(0.01,0.1,1$ ve $10 \mu \mathrm{M})$ eklenen DLT'nin 24 ve 48 saat sonunda toplam antioksidan, oksidan, malondialdehit (MDA) ve 8-hidroksi-2'-deoksiguanozin (8-OHdG) seviyeleri belirlenmiştir. Uygulanan en yüksek DLT konsantrasyonu $(10 \mu \mathrm{M}) 48$ saatte toplam oksidan seviyesinde önemli bir artışa neden olurken, 24 ve 48 saatte toplam antioksidan seviyesinde bir azalma tespit edildi $(P<0.05)$. Doymamış yağ asitlerinin lipid peroksidasyonunun ürünü olan MDA seviyesindeki artış, 24 ve 48 saat sonunda 1-10 $\mu \mathrm{M}$ DLT konsantrasyonları ile anlamlı bulunmuştur $(\mathrm{P}<0.05)$. DLT uygulama konsantrasyonlarının hiçbirinde 8-OHdG seviyesinde herhangi bir değişiklik gözlenmedi ( $\mathrm{P}>0.05)$. Sonuç olarak, 1 ve $10 \mu \mathrm{M}$ konsantrasyonlara maruz bırakılan Van Gölü balıklarının primer solungaç hücre kültüründe DLT'nin oksidatif strese neden olduğu ancak herhangi bir genotoksik etkinin gözlenmediği söylenebilir.
\end{abstract}

Anahtar kelimeler: Pestisit, Oksidatif stres, Lipid peroxidasyon, DNA hasarı, Van Gölü.

\section{Introduction}

Although pesticides are produced for agricultural pests, they are chemicals that have destructive effects on nontarget organisms as a result of water, food, and different contaminations. Deltamethrin (DLT) [(S)-a-cyano-3phenoxybenzyl-(S)-2-(4-chlorophenyl)-3-methyl

butyrate], which has been produced synthetically since 1974 to control pests in agricultural production, is widely used worldwide as a pyrethroid insecticide ( $\mathrm{Lu}$ et al., 2019). Like other pyrethroids, it has highly toxic effects on fish and other aquatic organisms. In particular, these pyrethroids have a median lethal dose $\left(\mathrm{LD}_{50}\right)$ of 100 to 1000 times lower in fish than in mammals and birds (Bradbury \& Coats, 1989; Paul \& Simonin, 2006). These pyrethroids have been reported to have adverse effects on fish reproduction, development, behavioral physiology, and different organs (Köprücü \& Aydın, 2004; Cengiz, 2006; Benli et al., 2009). It has been reported that enzymes that are effective in pesticide detoxification, especially in fish liver, are quite low when compared to those in mice
(Glickman \& Lech, 1982; Wheelock et al., 2005). DLT can accumulate in sediment, benthic organisms, and food particles due to its lipophilicity. There have been studies showing that it causes toxicity in many fish species (Yildirim et al., 2006; Amin \& Hashem, 2012; Hedayati \& Tarkhani, 2014; Petrovici et al., 2020). Reactive oxygen species (ROS) can react with biological macromolecules, such as DNA, lipids, and proteins, in living things. As a result of this reaction, it can cause cell death. If ROS cannot be removed from the cells by the antioxidant defense system, it causes oxidative stress. It is known that pesticides cause a great deal of damage in living creatures by increasing ROS (Bagchi et al., 1995; Monteiro et al., 2006). Animal cell culture is the process of cells continuing to live outside of the body under certain conditions. Studies with cell cultures constitute an important part of popular research topics today. Cell cultures are conducted to determine the effects of a particular substance or the functions of a certain biological molecule or molecules produced in a cell or tissue. Various studies can be 
performed on cells propagated from a specific cell line in cell culture or in primary cultures made from a specific organ and trials that cannot be done in vivo can be made and results can be obtained. It has many advantages over in vivo studies. One of the most important of these advantages is that it minimizes the number of living specimens used in in vivo studies (Freshney, 2015). Lake Van is located in the eastern Anatolian region of Turkey and is also among the largest soda lakes in the world. Only one vertebrate species, the Lake Van fish, has adapted to the extreme characteristics of the lake. Although attempts have been made to adapt other fish species to the extreme conditions of the lake, they were not successful (Danulat \& Selçuk, 1992). There has been a decrease in the population level of Lake Van fish in recent years (Freyhof, 2014). Although overfishing and habitat destruction have been shown as the reason for the decrease in the population level, the effect of the increasing pollution in the lake cannot be ignored. Lake Van fish is the only vertebrate species living in the lake; thus, it plays a very useful role as an indicator in determining lake pollution. In vitro studies are more advantageous than in vivo studies as they use fewer living things and create a more controllable environment. In this study, changes in the total antioxidant status (TAS), total oxidant status (TOS), malondialdehyde (MDA), and 8-hydroxy-2'deoxyguanosine (8-OHdG) levels in Lake Van fish primary gill cell culture of DLT, which is one of the pesticides used extensively in agricultural production in the Lake Van basin, were investigated.

\section{Material and Methods}

\subsection{Fish}

The living fish (3+ years old) used in this study were caught using sprinkle nets from the Karasu Stream that pours into Lake Van during the breeding season (Figs. 1A $\& 1 B)$. The fish were adapted for seven days by attaching an air stone to fiberglass tanks with $300 \mathrm{~L}$ of rested chlorine-free tap water (temperature: $13.1 \pm 2^{\circ} \mathrm{C}, \mathrm{pH}$ of 8.57 \pm 0.4 , dissolved oxygen: $6.41 \pm 0.14 \mathrm{mg} / \mathrm{L}$, oxygen saturation: $61.1 \% \mathrm{~L}$, conductivity: $731 \mathrm{mS} / \mathrm{cm}$, salinity: $0.47 \%)$. During the experiment, they were fed commercial trout feed once a day. Animal experimental procedures were conducted in accordance with the animal study protocols $(2018 / 5)$ approved by the Van Yüzüncü Y1l University Animal Experiments Local Ethics Committee.

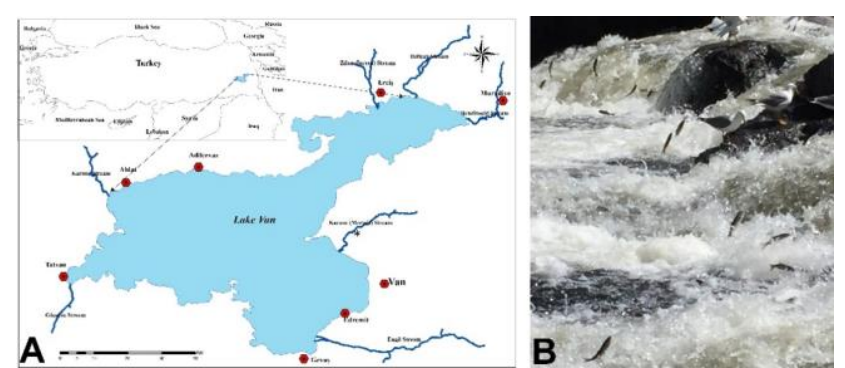

Figure 1. Karasu stream flowing into the lake where the Lake Van fish were caught using a sprinkle net (A) and breeding migration of the fish (B).

\subsection{Primary gill cell isolation and cell culture}

In order to prevent the study from being affected by anesthetic agents, the fish were euthanized and decapitation was performed. The gill springs were removed and placed into phosphate-buffered saline (PBS) (136.9 mM NaCl, $8.06 \mathrm{mM} \mathrm{Na}_{2} \mathrm{PO}_{4}, 2.68 \mathrm{mM} \mathrm{KCl}, 1.47 \mathrm{mM}$ $\mathrm{KH}_{2} \mathrm{PO}_{4}$ ). The gill filaments were cut into small pieces using a scalpel. They were then treated with PBS containing antibiotics and antimycotic $\left(18^{\circ} \mathrm{C}, 10 \mathrm{~min}\right)$. The filaments were placed in a solution containing trypsin enzyme and kept in a shaker for 20 min (this process was repeated twice). The cell suspension was then filtered through an $80-\mu \mathrm{m}$ filter into PBS containing fetal bovine serum (FBS). The suspension was centrifuged at $250 \mathrm{Xg}$. Cells were washed with PBS containing 2\% FBS and centrifuged at $250 \mathrm{Xg}$ for $8 \mathrm{~min}$. Next, the cells were suspended in 5\% FBS and medium containing antibioticantimycotic and; then, they were placed into appropriate cell culture dishes (Part et al., 1993). Dead-alive cell count was performed under a microscope by staining the isolated cell suspension with trypan blue. After it was determined that more than $90 \%$ of the cells were viable, they were placed in poly-L-lysine-coated 48-well cell dishes. The $\mathrm{pH}$ change and microbial contamination in the cell culture dishes were observed via microscopic observations during the experimental period. DLT $(0.01$, $0.1,1$, and $10 \mu \mathrm{M})$ was added onto the cells. The proportion of solvent used in the culture medium was set not to exceed $1 \%$.

\subsection{Determination of TAS and TOS levels}

The TAS and TOS levels, developed by Erel (2004), were determined by mass using the Rel Diagnostics Assay kit (Mega Medicine, Gaziantep, Turkey). According to the method used for the TAS measurement, the antioxidant effect of the sample against strong free radical reactions of the generated hydroxyl radical was measured. Results were expressed in $\mu \mathrm{mol}$ Trolox Eq/L (Erel, 2004). According to the method used for the TOS measurement, the total amount of oxidant molecules in the sample was related to the color density that could be measured spectrophotometrically. Calibration of the test was done using hydrogen peroxide $\left(\mathrm{H}_{2} \mathrm{O}_{2}\right)$. Results were expressed as micromolar hydrogen peroxide equivalent per liter $\left(\mu \mathrm{mol} \mathrm{H}{ }_{2} \mathrm{O}_{2} \mathrm{Eq} / \mathrm{L}\right)$ (Erel, 2005).

\subsection{Determination of MDA concentrations}

MDA is a product of lipid peroxidation (LPO) which was measured in terms of the MDA concentration using the thiobarbituric acid reaction (John \& Steven, 1978)

\subsection{8-OHdG assay}

DNA damage in gill cells was determined using readymade commercial ELISA kits for $8-\mathrm{OHdG}$ content. Samples taken at the end of 24 and $48 \mathrm{~h}$ were extracted and evaluated according to the commercial kit procedures. Finally, the absorbance values of the samples were measured at $450 \mathrm{~nm}$ in a microplate reader. Values were calculated using the graphics obtained from the standards in the kit (Bioassay Technology Laboratory, Shanghai, China). The 8-OHdG content was expressed as $\mathrm{ng} / \mathrm{mL}$.

\subsection{Statistical analysis}

The data were expressed as the mean \pm standard error of the mean (SEM). Raw data were analyzed by using statistical package software (SPSS 11.5, IBM Corp., Armonk, NY, USA). Between group comparisons were performed with a one-way ANOVA and Duncan's multiple comparison 
tests. Significance was accepted at $\mathrm{P}<0.05$.

\section{Results}

As a result of the primary gill cell isolation of Lake Van fish, it was determined that the gill cell morphology was round in appearance under the microscope. Erythrocytes were observed in the culture because the tissue contained much blood. However, the total erythrocytes did not exceed $10 \%$ of the gill cells. No contamination was observed in the cell culture during the experiment. There was no change in the TOS level at $24 \mathrm{~h}$ of exposure to DLT; however, but it was determined that it caused an increase with 1 and $10 \mu \mathrm{M}$ of DLT at $48 \mathrm{~h}(\mathrm{P}<0.05)$ (Fig. 2). When the groups exposed to DLT and the control were compared in terms of the TAS level, the decrease with all of the DLT concentrations at $48 \mathrm{~h}$ and with $10 \mu \mathrm{M}$ at $24 \mathrm{~h}$ was found to be significant $(\mathrm{P}<0.05)$ (Fig. 3). For the MDA levels, which is a product of LPO, an increase was observed with $10 \mu \mathrm{M}$ of DLT at $24 \mathrm{~h}$ and with $1-10 \mu \mathrm{M}$ of DLT at $48 \mathrm{~h}$ $(\mathrm{P}<0.05)$ (Fig. 4). No significant change was observed in the 8-OHdG level, which is a marker of DNA damage, with any of the DLT concentrations of at 24 or $48 \mathrm{~h}(\mathrm{P}>0.05)$ (Fig. $5)$.

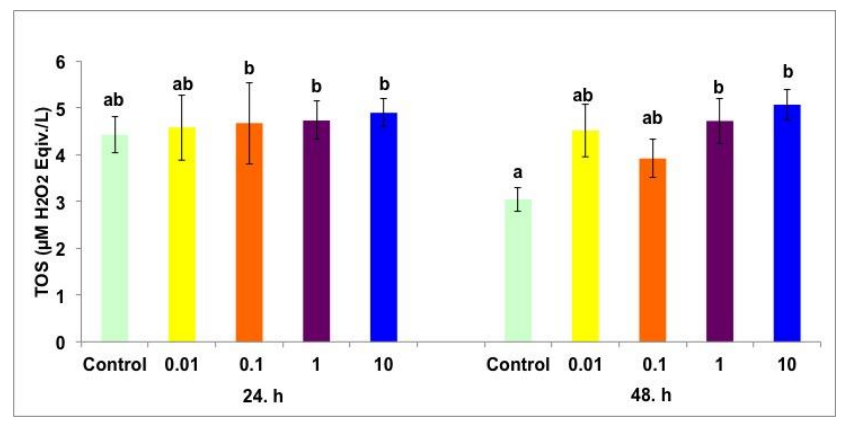

Figure 2. Changes in total oxidant status activity in Lake Van fish gill primary cell culture exposed to different concentrations of deltamethrin. Different letters represent statistical significance at $\mathrm{P}<0.05$. Values are expressed as the mean \pm SEM (n: 6).

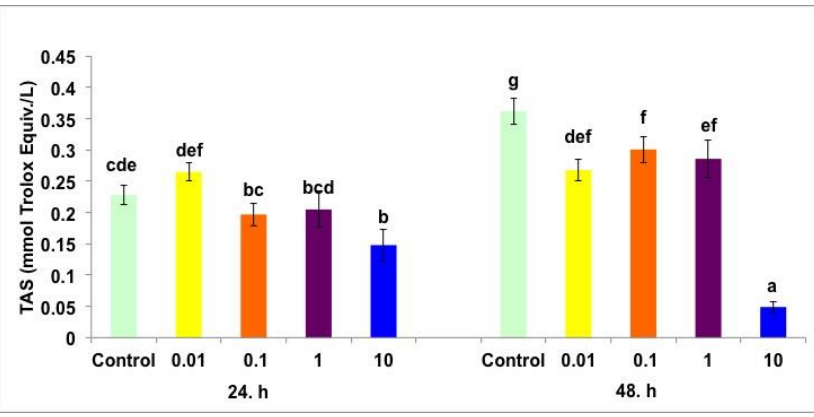

Figure 3. Changes in total antioxidant status activity in Lake Van fish gill primary cell culture exposed to different concentrations of deltamethrin. Different letters represent statistical significance $(\mathrm{P}<0.05)$. Values are expressed as the mean $\pm \mathrm{SEM}(\mathrm{n}: 6)$.

\section{Discussion}

Pesticides play an important role in the formation of ROS. The immune systems of fish are significantly affected by toxic substances. Reaction to toxic substances can be either activating or suppressive. However, this activation does not mean that the immune system becomes stronger or resistant (Ghelichpour et al., 2019; Mirghaed et al., 2020). Gills are multifunctional organs in fish (Wang et al., 2016). Oxidative damage caused by chemicals in aquatic ecosystems can be evaluated by measuring the enzymatic

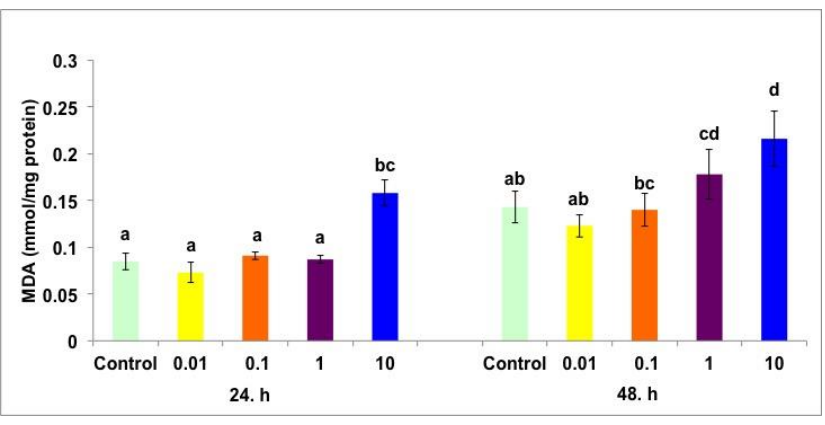

Figure 4. Changes in malondialdehyde level in Lake Van fish gill primary cell culture exposed to different concentrations of deltamethrin. Different letters represent statistical significance at $\mathrm{P}<0.05$. Values are expressed as the mean \pm SEM (n: 6).

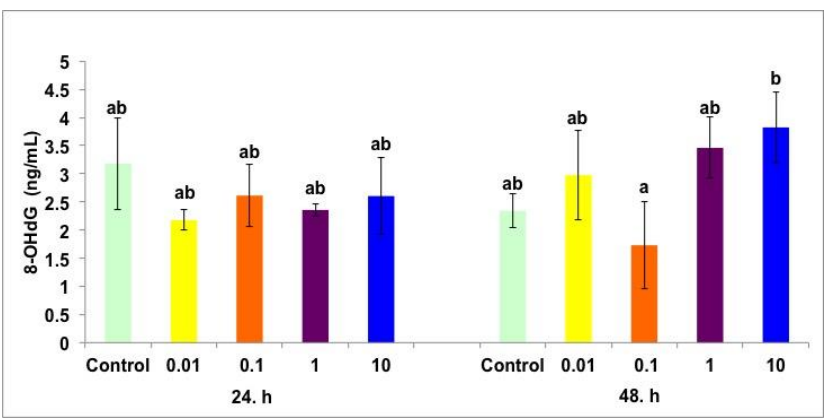

Figure 5. Changes in 8-hydroxy-2'-deoxyguanosine level in Lake Van fish gill primary cell culture exposed to different concentrations of deltamethrin. Different letters represent statistical significance at $\mathrm{P}<0.05)$. Values are expressed as the mean \pm SEM (n: 6).

and nonenzymatic antioxidant profiles in fish (Slaninova et al., 2009). There have been many studies with DLT on fish and it has been reported that this pyrethroid is a source of oxidative stress. In this context, in a study conducted with DLT, it was suggested that it reduced hepatic and renal antioxidant levels [catalase (CAT), superoxide dismutase (SOD), glutathione (GSH)] in the liver and kidneys, and increased MDA levels (Abdel-Daim et al., 2013). In a study on primary hepatocyte culture in Lake Van fish, fish primary cell culture exposed to $10 \mu \mathrm{M}$ of DLT for $24 \mathrm{~h}$ was found to have a significant increase $(\mathrm{P}<0.05)$ while the increase seen in fish exposed to $10 \mu \mathrm{M}$ of DLT for $48 \mathrm{~h}$ was nonsignificant (Kiraççakali \& Oğuz, 2020). DLT $(65.6 \mu \mathrm{g} / \mathrm{L})$ has been reported to reduce the activity of antioxidant enzymes, such as SOD, CAT, and glutathione reductase, in common carp (Cyprinus carpio L) exposed for $96 \mathrm{~h}$ and cause oxidative damage in the gills, liver, and kidneys (Stara et al., 2015). In freshwater fish (Channa punctatus Bloch) exposed to DLT $(0.75 \mu \mathrm{g} / \mathrm{L})$ for $46 \mathrm{~h}$, an increase was observed in the levels of glutathione peroxidase and glutathione-S-transferase against ROS damage in the liver and kidneys while a significant decrease in CAT activity was reported. Significant increases were observed in LPO (MDA) levels in all tissues (Sayeed et al., 2003). Increased LPO is an indicator of oxidative damage (Pinedo-Gil et al., 2018). ROS increase the oxidation of polyunsaturated fatty acids in the cell membrane structure (Blahova et al., 2013). It has been observed that LPO increases due to various pesticides in fish (Rao, 2006; Üner et al., 2006). LPO is one of the most important biomarkers of oxidative stress in fish and it causes the impairment of cellular function through its destructive effects on biomolecules under oxidant conditions (Nunes et al., 2018). The current study showed 
that the increase in the TOS, decrease in the TAS, and increase in MDA levels in the Lake Van fish primary cell culture were associated with the increased concentration of DLT and prolonged exposure (Figs. 2-4). These results were similar to those of studies related to DLT exposure. The increased 8-OHdG activity of the pyrethroids in the gill tissues of fish may be a response to oxidative stress. 8$\mathrm{OHdG}$ is an indicator used in the determination of the toxicity of many chemicals. In this study, it was observed that DLT did not cause DNA damage at the end of 24 and $48 \mathrm{~h}$ in the Lake Van fish primary gill culture. The reason why this pyrethroid did not show a significant increase in the 8-OHdG level in the gill cell culture may have been due to the short exposure time.

Gonad anomalies in Lake Van fish sampled from Lake Van were shown in previous studies (Ünal et al., 2007; Oğuz \& Yeltekin, 2014). It was reported that DLT causes toxic effects on the gonads in addition to oxidative stress in fish (Petrovici et al., 2000). Gonad anomalies observed in Lake Van fish may have been caused by DLT or similar pyrethroids. For this reason, studies and measures such as the quantification of pesticides in Lake Van and restrictions on the use of these pyrethroids should be taken.

Acknowledgements: This study was supported by the Scientific Research Projects Coordinator of Van Yüzüncü Yll University under project number FBA-2019-7491. I would like to thank Necati ÖZOK and Ahmet R. OĞUZ for their contribution to the laboratory studies herein.

Ethics committee approval: Animal experimental procedures were conducted in accordance with animal study protocols (2018/5) approved by the Van Yüzüncü Yıl University Animal Experiments Local Ethics Committee.

Conflict of interest: The author declares that there is no conflict of interest.

\section{References}

Abdel-Daim, M.M., Abuzead, S.M., \& Halawa, S.M. (2013). Protective role of Spirulina platensis against acute deltamethrin-induced toxicity in rats. PLoS One 8(9), e72991. https:// doi.org/10.1371/journal.pone.0072991

Amin, K.A., \& Hashem, K.S. (2012). Deltamethrin-induced oxidative stress and biochemical changes in tissues and blood of catfish (Clarias gariepinus): antioxidant defense and role of alpha-tocopherol. BMC Veterinary Research, 8(1), 45. https://doi.org/10.1186/1746-6148-8-45

Bagchi, D., Bagchi, M., \& Hassoun, E.A. (1995). In vitro and in vivo generation of reactive oxygen species, DNA damage and lactate dehydrogenase leakage by selected pesticides. Toxicology, 104(1-3), 129_ 140. https:// doi.org/10.1016/0300-483x(95)03156-a.

Benli, A., Selvi, M., \& Sarikaya, R. (2009). Acute Toxicity of Deltamethrin on Nile Tilapia (Oreochromis niloticus L. 1758) Larvae and Fry. Gazi University Journal of Science, 22(1), 1-4.

Blahova, J., Plhalová, L., \& Hostovský, M. (2013). Oxidative stress responses in zebrafish (Danio rerio) after 319 subchronic exposure to atrazine. Food $\begin{array}{llll}\text { and Chemical } & \text { Toxicology, } & \text { 82-85. }\end{array}$ https://doi.org/10.1016/j.fct.2013.02.041.

Bradbury, S.P., \& Coats, J.R. (1989). Toxicokinetics and toxicodynamics of pyrethroid insecticides in fish. Environmental Toxicology and Chemistry, 8(5), 373-380. https:/ / doi.org/10.1002/ etc.5620080503

Cengiz, E.I. (2006). Gill and kidney histopathology in the freshwater fish Cyprinus carpio after acute exposure to deltamethrin. Environmental Toxicology and Pharmacology, 22(2), 200-204. https://doi.org/10.1016/i.etap.2006.03.006

Danulat, E., \& Selçuk, B. (1992). Life history and environmental conditions of the anadromous Chalcalburnus tarichi (Cyprinidae) in the highly alkaline Lake Van, eastern Anatolia, Turkey. Archiv für Hydrobiologie, 126(1), 105-125.
Erel, O. (2004). A novel automated direct measurement method for total antioxidant capacity using a new generation, more stable ABTS radical cation. Clinical Biochemistry, 37(4), 277-285. https://doi.org/10.1016/j.clinbiochem.2003.11.015.

Erel, O. (2005). A new automated colorimetric method for measuring total oxidant status. Clinical Biochemistry, 38(12), 1103-1111. https://doi.org/10.1016/j.clinbiochem.2005.08.008

Freshney, R.I. (2015). Culture of animal cells: a manual of basic technique and specialized applications. John Wiley \& Sons.

Freyhof, J. (2014). Alburnus tarichi. The IUCN Red List of Threatened Species. 2014: e.T4375A19222678.

Ghelichpour, M.T., Mirghaed, A., \& Hoseini, S.M. (2019). Plasma antioxidant and hepatic enzymes activity, thyroid hormones alterations and health status of liver tissue in common carp (Cyprinus carpio) exposed to lufenuron. Aquaculture, 516, 734634. https://doi.org/10.1016/j.aquaculture.2019.734634

Glickman, A.H., \& Lech, J.J. (1982). Differential toxicity of trans-permethrin in rainbow trout and mice: II. Role of target organ sensitivity. Toxicology and Applied Pharmacology, 66(2) 162-171. https://doi.org/10.1016/0041-008X(82)90280-0

Hedayati, A., \& Tarkhani, R. (2014). Hematological and gill histopathological changes in iridescent shark, Pangasius hypophthalmus (Sauvage, 1878) exposed to sublethal diazinon and deltamethrin concentrations. Fish Physiology and Biochemistry, 40(3), 715-720. https://doi.org/10.1007/s10695-013-9878-3.

John, A.B., \& Steven, D.A. (1978). Microsomal lipid peroxidation in methods in enzymology. New York: Academic Press, 302-310 pp.

Kiraççakali, A.N., \& Oğuz, A.R. (2020). Determination of cytotoxic, genotoxic, and oxidative damage from deltamethrin on primary hepatocyte culture of Lake Van fish, Alburnus tarichi. Chemistry and Ecology, 36(7), 651-662. https:// doi.org/10.1080/02757540.2020.1781098

Köprücü, K., \& Aydın, R. (2004). The toxic effects of pyrethroid deltamethrin on the common carp (Cyprinus carpio L.) embryos and larvae. Pesticide Biochemistry and Physiology, 80(1), 47-53. https://doi.org/10.1016/j.pestbp.2004.05.004

Lu, Q., Sun, Y, \& Ares, I. (2019). Deltamethrin toxicity: A review of oxidative stress and metabolism. Environmental Research, 170, 260-281. https://doi.org/10.1016/j.envres.2018.12.045.

Mirghaed, A.T., Baes, M., \& Hoseini, S.M. (2020). Humoral immune responses and gill antioxidant-related gene expression of common carp (Cyprinus carpio) exposed to lufenuron and flonicamide. Fish Physiology and Biochemistry, 46(2), 739-746. https://doi.org/10.1007/s10695-01900747-x.

Monteiro, D.A., De Almeida, J.A., \& Rantin, F.T. (2006). Oxidative stress biomarkers in the freshwater characid fish, Brycon cephalus, exposed to organophosphorus insecticide Folisuper 600 (methyl parathion). Comparative Biochemistry and Physiology Part C: Toxicology $\mathcal{E}$ $\begin{array}{llr}\text { Pharmacology, } & 143(2), & 141-149 .\end{array}$ https://doi.org/10.1016/i.cbpc.2006.01.004

Nunes, M.E., Müller, T.E., \& Murussi, C. (2018). Oxidative effects of the acute exposure to a pesticide mixture of cypermethrin and chlorpyrifos on carp and zebrafish- A comparative study. Comparative Biochemistry and Physiology Part C: Toxicology \& Pharmacology, 206, 48-53. https://doi.org/10.1016/j.cbpc.2018.03.002

Oğuz, A.R., \& Yeltekin, A. (2014). Metal levels in the liver, muscle, gill, intestine, and gonad of Lake Van fish (Chalcalburnus tarichi) with abnormal gonad. Biological Trace Element Research, 159(1-3), 219-223. https://doi.org/10.1007/s12011-014-9980-0.

Part, P., Norrgren, L., Bergstrom, E., \& Sjoberg, P. (1993). Primary cultures of epithelial cells from rainbow trout gills. Journal of Experimental Biology, 175(1), 219-232. https:/ / doi.org/10.1242/jeb.175.1.219

Paul, E.A., \& Simonin, H.A. (2006). Toxicity of three mosquito insecticides to crayfish. Bulletin of Environmental Contamination and Toxicology, 76(4), 614-621. https://doi.org/10.1007/s00128-006-0964-4.

Petrovici, A., Strungaru, S.A., \& Nicoara, M. (2020). Toxicity of deltamethrin to zebrafish gonads revealed by cellular biomarkers. Journal of Marine Science and Engineering, 8(2), 73. https://doi.org/10.3390/jmse8020073

Pinedo-Gil, J., Martín-Diana, A.B., \& Bertotto, D. (2018). Effects of dietary inclusions of red beet and betaine on the acute stress response and muscle lipid peroxidation in rainbow trout. Fish Physiology and Biochemistry, 44(3), 939-948. https://doi.org/10.1007/s10695-018-04833.

Rao, J.V. (2006). Toxic effects of novel organophosphorus insecticide (RPRV) on certain biochemical parameters of euryhaline fish, Oreochromis 
mossambicus. Pesticide Biochemistry and Physiology, 86(2), 78-84. https://doi.org/10.1016/j.pestbp.2006.01.008

Sayeed, I., Parvez, S., \& Pandey, S. (2003). Oxidative stress biomarkers of exposure to deltamethrin in freshwater fish, Channa punctata Bloch. Ecotoxicology and Environmental Safety, 56, 295-301. https://doi.org/10.1016/S0147-6513(03)00009-5

Slaninova, A., Smutna, M., \& Modra, H. (2009). A review: oxidative stress in fish induced by pesticides. Neuro Enocrinology Letters, 30, 2-12.

Stara, A., Zuskova, E., \& Machova, J. (2015). Effects of acute exposure to deltamethrin and recovery time on common carp (Cyprinus carpio L.). Neuro Enocrinology Letters, 36, 133-140.

Ünal, G., Türkoğlu, V., \& Oğuz, A.R. (2007). Gonadal histology and some biochemical characteristics of Chalcalburnus tarichi (Pallas, 1811) having abnormal gonads. Fish Physiology and Biochemistry, 33(2), 153-165. https://doi.org/10.1007/s10695-006-9126-1

Üner, N., Oruç, E.Ö., \& Sevgiler, Y. (2006). Effects of diazinon on acetylcholinesterase activity and lipid peroxidation in the brain of Oreochromis niloticus. Environmental Toxicology and Pharmacology, 21(3), 241-245. https://doi.org/10.1016/j.etap.2005.08.007.

Wang, Z.J., Liu, X.H., \& Jin, L. (2016). Transcriptome profiling analysis of rare minnow (Gobiocypris rarus) gills after waterborne cadmium exposure. Comparative Biochemistry and Physiology Part D: Genomics and Proteomics, 19, 120-128. https://doi.org/10.1016/j.cbd.2016.05.003.

Wheelock, C.E., Eder, K.J., \& Werner, I. (2005). Individual variability in esterase activity and CYP1A levels in Chinook salmon (Oncorhynchus tshawytscha) exposed to esfenvalerate and chlorpyrifos. Aquatic Toxicology, 74(2), 172-192. https://doi.org/10.1016/j.aquatox.2005.05.009.

Yildirim, M.Z., Benli, A.Ç.K., \& Selvi, M. (2006). Acute toxicity, behavioral changes, and histopathological effects of deltamethrin on tissues (gills, liver, brain, spleen, kidney, muscle, skin) of Nile tilapia (Oreochromis niloticus L.) fingerlings. Environmental Toxicology, 21(6), 614-620. https://doi.org/10.1002/tox.20225. 